\title{
Blockade of bovine PD-1 increases T cell function and inhibits bovine leukemia virus expression in B cells in vitro
}

Ryoyo Ikebuchi ${ }^{1}$, Satoru Konnai ${ }^{1}$, Tomohiro Okagawa' ${ }^{1}$ Kazumasa Yokoyama ${ }^{2}$, Chie Nakajima ${ }^{2}$, Yasuhiko Suzuki ${ }^{2}$, Shiro Murata ${ }^{1}$ and Kazuhiko Ohashi ${ }^{*}$

\begin{abstract}
Programmed death-1 (PD-1) is a known immunoinhibitory receptor that contributes to immune evasion of various tumor cells and pathogens causing chronic infection, such as bovine leukemia virus (BLV) infection. First, in this study, to establish a method for the expression and functional analysis of bovine PD-1, hybridomas producing monoclonal antibodies (mAb) specific for bovine PD-1 were established. Treatment with these anti-PD-1 mAb enhanced interferon-gamma (IFN- $\gamma$ ) production of bovine peripheral blood mononuclear cells (PBMC). Next, to examine whether PD-1 blockade by anti-PD-1 mAb could upregulate the immune reaction during chronic infection, the expression and functional analysis of PD-1 in PBMC isolated from BLV-infected cattle with or without lymphoma were performed using anti-PD-1 mAb. The frequencies of both PD-1 $1^{+} \mathrm{CD} 4^{+} \mathrm{T}$ cells in blood and lymph node and PD- $1^{+} \mathrm{CD}^{+} \mathrm{T}$ cells in lymph node were higher in BLV-infected cattle with lymphoma than those without lymphoma or control uninfected cattle. PD-1 blockade enhanced IFN- $\gamma$ production and proliferation and reduced BLV-gp51 expression and B-cell activation in PBMC from BLV-infected cattle in response to BLV-gp51 peptide mixture. These data show that anti-bovine PD-1 mAb could provide a new therapy to control BLV infection via upregulation of immune response.
\end{abstract}

\section{Introduction}

Immunoinhibition is considered one of the reasons responsible for the refractory nature of several types of tumors and chronic infections [1,2]. One of them, bovine leukemia virus (BLV) is known to induce immunosuppression and B cell lymphoma in cattle, and lead to enormous damages to livestock industries around the world [3]. BLV establishes a chronic infection in B cells for several years until infected cattle develop B-cell lymphoma mainly in lymphoid tissue, although neither viral RNA nor protein expression was readily detected in vivo or freshly isolated lymphocytes [4,5]. During the chronic infection, the suppression of both $\mathrm{CD} 4^{+} \mathrm{T}$ cell proliferation and cytotoxic immune response against BLV antigens is correlated to disease progression $[3,6]$. To develop strategies to effectively control BLV

\footnotetext{
* Correspondence: okazu@vetmed.hokudai.ac.jp

'Department of Disease Control, Graduate School of Veterinary Medicine, Hokkaido University, Sapporo 060-0818, Japan

Full list of author information is available at the end of the article
}

infection, the mechanism responsible for this immunosuppression needs to be clarified.

Programmed death-1 (PD-1) has been recognized as being at the heart of peripheral immune tolerance and pathogen-specific immunoinhibition [2]. In various types of chronic infections and tumors, PD-1 and its ligand, PD-ligand-1 (PD-L1) play an important role in inhibiting chronically activated $\mathrm{T}$ cells specific for pathogens, resulting in the induction of "exhausted" $\mathrm{T}$ cells [5,7-9]. Treatment with monoclonal antibodies $(\mathrm{mAb})$ specific for either PD-1 or PD-L1 reactivates exhausted immune responses such as proliferation, cytokine production, and cytotoxic capabilities of exhausted $\mathrm{T}$ cells ex vivo $[7,10]$, and in vivo $[11,12]$, and was tested in clinical trials with cancer patients $[13,14]$.

In the field of veterinary medicine, the PD-1/PD-L1 pathway was also investigated in the pig $[15,16]$, chicken [17] and cat [18] and found to contribute to pathogenesis and immune evasion of chronic infectious diseases. Our previous reports also showed that the expression of 
PD-L1 in B cells which were target cells for BLV, was upregulated in $\mathrm{BLV}$-infected $\left(\mathrm{BLV}^{+}\right)$cattle as the disease progressed, and PD-L1 blockade upregulated expressions of interferon-gamma (IFN- $\gamma$ ) and interleukin (IL)-2 mRNA in peripheral blood mononuclear cells (PBMC) in vitro [19]. The expression levels of $P D-1$ mRNA were upregulated in $\mathrm{CD}^{+}$and $\mathrm{CD}^{+} \mathrm{T}$ cells isolated from $\mathrm{BLV}^{+}$cattle with B-cell lymphoma (BCBL) [20].

In previous reports, anti- "human" PD-1 or PD-L1 "polyclonal" antibodies (pAb) were used to analyze their expression and to block the PD-1/PD-L1 pathway $[18,19]$. Under some experimental conditions, anti-PD-1 pAb induced IL-10 production by monocytes, resulting in the inhibition of $\mathrm{CD}^{+} \mathrm{T}$ cell function [21]. However, at the present time, mAb specific for animal PD-1 and PD-L1 which can reactivate exhausted immune reaction are not available, although they are essential for further investigation and development of new therapy for refractory diseases, such as BLV infection. In this study antibovine PD-1 mAb were established and their functional capabilities were assessed using PBMC from $\mathrm{BLV}^{+}$and $\mathrm{BLV}$-uninfected $\left(\mathrm{BLV}^{-}\right)$cattle in vitro. The upregulation of PD-1 expression was found in $\mathrm{CD}^{+}$and $\mathrm{CD}^{+} \mathrm{T}$ cells isolated from BCBL. The treatment with an anti-PD-1 mAb upregulated IFN- $\gamma$ production and reduced both $\mathrm{B}$ cell activation and BLV-gp51 expression in PBMC isolated from $\mathrm{BLV}^{+}$cattle. These data suggest that anti-PD $-1 \mathrm{mAb}$ can be applicable for antibody drug to control BLV infection.

\section{Materials and methods Construction and expression of recombinant soluble bovine PD-1-immunoglobulin fusion protein}

Soluble PD-1-bovine IgG1 fusion protein (PD-1-Ig) was expressed in a mammalian cell expression system. The extracellular domain fragment of bovine PD-1 was amplified and the fragment was inserted into the cloning site of a modified pCAGGS (provided by Dr J. Miyazaki, Osaka University; [22]) that contained a mouse CD150 leader sequence at the $\mathrm{N}$ terminus and the $\mathrm{F}_{\mathrm{c}}$ fragment of bovine IgG1 at the $\mathrm{C}$ terminus [23]. PD-1-Ig was produced in Cos-7 cells transfected transiently by Lipofectamine 2000 (Life Technologies, Carlsbad, CA, USA) and purified from the media with Protein G Sepharose 4 Fast Flow (GE Healthcare UK Ltd, Buckinghamshire, UK) according to the manufacturer's protocol. The expression and purification of PD-1-Ig was confirmed by sodium dodecyl sulfate-polyacrylamide gel electrophoresis (SDS-PAGE) and enzyme-linked immunosorbent assay (ELISA) using antibovine IgG-Fc (Rockland Immunochemicals, PA, USA).

Generation and screening of mAb specific for bovine PD-1 To obtain mAb specific for bovine PD-1, a rat was immunized with about $66 \mu \mathrm{g}$ of PD-1-Ig and complete
Freund adjuvant. Nineteen days later, $100 \mu \mathrm{g}$ of PD-1-Ig was shot into the rat as a boost. On the $24^{\text {th }}$ day of the first immunization, lymphocytes isolated from the iliac lymph node ( $\mathrm{LN}$ ) were fused with myeloma cells and cloned, and the supernatants from hybridomas were screened by ELISA for the reactivity of culture supernatant with PD-1-Ig. Clones that produce antibodies specific for bovine IgG1-Fc were excluded by ELISA using bovine IgG as an antigen. The immunization of rats and ELISA was performed at Cell Engineering Corporation (Osaka, Japan). The hybridomas were also screened by flow cytometry using Cos-7 cells that were transfected with bovine PD-1 coding pCMV-Tag-1 (Agilent Technologies, CA, USA). Hybridomas producing antibodies that reacted with transfected but not untransfected PD-1 Cos-7 cells were cloned by limiting dilution.

\section{Western blotting}

To test the reactivity of anti-bovine PD-1 mAb, Western blot analysis was performed using Chinese hamster ovary (CHO)-DG44 cells (provided by Dr Y. Suzuki) that stably express bovine PD-1. CHO-DG44 cells were transfected with bovine PD-1 coding pCMV-Tag-1 using Lipofectamine Ltx (Life Technologies). Transfectants were selected in CD-DG44 (Life Technologies) containing G418 sulfate (Wako, Osaka, Japan; $800 \mu \mathrm{g}$ / $\mathrm{mL}$ ) for two weeks. The cells were then incubated with anti-bovine PD-1 mAb (produced from our hybridoma, 5D2), followed by incubation with Anti-Rat IgG Micro beads (Miltenyi Biotec, Bergisch Gladbach, Germany). CHO-DG44 cells highly expressing PD-1 were sorted by auto MACS Pro (Miltenyi Biotec), cultivated for a week, and then re-sorted. $\mathrm{CHO}$ cells transfected with noncoding pCMV-Tag-1 were selected in the same way and used as a negative control. The cells were lysed in $2 \times$ SDS buffer (125 mM Tris- $\mathrm{HCl} \mathrm{pH} 6.8,4 \%$ SDS, 10\% 2-mercaptoethanol, and 20\% glycerol) and boiled for $10 \mathrm{~min}$. The samples were separated on $12 \%$ SDS-polyacrylamide gels and transferred onto a polyvinylidene difluoride membrane (Merck Millipore, MA, USA). After being blocked with $3 \%$ skim milk in phosphate-buffered saline (PBS, $\mathrm{pH}$ 7.2) containing $0.05 \%$ Tween 20 (PBS-T), the membranes were incubated at room temperature for $2 \mathrm{~h}$ with anti-PD-1 $\mathrm{mAb}(2 \mathrm{C} 12$ and 3G2: $3 \mu \mathrm{g} / \mathrm{mL}, 2 \mathrm{H} 7$ and 5D2: $1 \mu \mathrm{g} /$ $\mathrm{mL}$ ), followed by washing and incubation with horse radish peroxidase (HRP)-conjugated anti-rat IgG (MP Biomedicals, CA, USA). The membrane was also probed with anti-Actin antibody (Merck Millipore; clone C4) and anti-myc tag antibody (Abcam, Cambridge, UK; goat polyclonal antibody) as loading control and positive control. After washing, the membranes were incubated with Immobilon Western 
Chemiluminescent HRP Substrate (Merck Millipore) to visualize signals, and analyzed with a Fluor-S Multi Imager (Bio-Rad Laboratories, CA, USA).

\section{Samples from cattle and BLV diagnosis}

Blood and mesenteric LN samples from Japanese black and Holstein-Friesian were investigated. In this study, we obtained blood samples from 95 cattle altogether (BLV+: 53, BLV-: 42) bred on several farms. They were collected in about ten installments. Peripheral venous blood was collected from cows into tubes containing sodium heparin (Ajinomoto, Tokyo, Japan). All of the cattle from which the blood samples were obtained had been diagnosed with BLV infection by nested PCR as described previously [19] at the Veterinary Teaching Hospital, Graduate School of Veterinary Medicine, Hokkaido University between 2008 and 2012. LN samples were provided by the Meat inspection center and veterinary hospitals in Japan, and diagnosed by nested-real time PCR using primers described previously [19]. The first amplification was conducted by KOD FX neo (Toyobo, Osaka, Japan) using less than 20000 LN cells as templates, and the second amplification was performed using SYBR Premix DimerEraser (Takara, Shiga, Japan). This study was conducted in accordance with the guidelines of the Institutional Animal Care and Use Committee of Hokkaido University, Japan. Samples were collected after informed consent was obtained from farmers.

To diagnose $\mathrm{B}$ cell lymphoma, phenotypic analysis of PBMC and/or tumor-bearing LN (mesenteric, iliac, gastric or superficial cervical LN) cells from BCBL which had been diagnosed clinically were performed by flow cytometry. Double staining were conducted using antibovine IgM (BIG73A; VMRD, WA, USA) pre-labeled with Zenon Alexa Fluor 488 (Life Technologies) and the following antibodies; anti-WC4 (CC55; CD19 like; AbD Serotec, Oxford, UK) [24], anti-B-B7 (GB25A; CD21 like; VMRD) and anti-bovine CD5 (CACT105A; VMRD). Alexa Fluor 647-conjugated anti-mouse IgG (Life Technologies) was used for the antibodies other than antiIgM as a secondary antibody. The samples in which more than $85 \%$ of the cells were $\mathrm{B}$ cells $\left(\mathrm{IgM}^{+} \mathrm{CD} 5^{+}\right.$, $\mathrm{IgM}^{-} \mathrm{WC4}^{+}$or $\mathrm{IgM}^{-} \mathrm{CD}^{+} 1^{+}$) were diagnosed as B-cell lymphoma induced by BLV. More than 30000 lymphocytes were analyzed.

\section{Cell preparation from blood and lymph nodes}

PBMC were purified from the blood samples by density gradient centrifugation on Percoll (GE Healthcare UK Ltd). LN tissues were minced in PBS and passed through a cell strainer (40 $\mu \mathrm{m}$; BD Biosciences, NJ, USA).

\section{PD-1 expression analysis}

To block nonspecific staining, 5-20 $\times 10^{5}$ PBMC were incubated in PBS containing $10 \%$ goat serum (Sigma-Aldrich, MO, USA) at room temperature for $15 \mathrm{~min}$. The cells were then washed and stained for PD1, CD4, CD8, IgM and CD25 for $30 \mathrm{~min}$ at room temperature. The following antibody conjugates were used in Figure 1: PD-1:5D2; CD4:CACT138A (VMRD) pre-labeled with Zenon Alexa Fluor 488; CD8:CACT80C (VMRD) pre-labeled with Lightning-Link PerCP/Cy5.5 (Innova Biosciences, Cambridge, UK); IgM:BIG73A prelabeled with Zenon PE (Life Technologies); CD25: CACT116A pre- labeled with Lightning-Link PE-Cy7 (Innova Biosciences). In Figure 2, the cells were stained with the following antibody: PD-1, CD4 pre-labeled with Zenon Alexa Fluor 488, CD8 pre-labeled with Lightning-Link PerCP/Cy5.5, and IgM pre-labeled with Lightning-Link PE-Cy7. After washing with PBS containing $10 \%$ goat serum, the cells were incubated with APC-conjugated anti-rat $\operatorname{IgM}+\operatorname{IgG}$ (Beckman Coulter, CA, USA) for $30 \mathrm{~min}$ at room temperature. The cells were then washed and immediately analyzed by FACS Verse (BD Biosciences) and FCS Express 4 (De Novo Software, CA, USA). No fewer than 40000 lymphocytes and no more than 160000 lymphocytes were analyzed among the samples.

To measure the upregulation of PD-1 expression in stimulated bovine lymphocytes isolated from $\mathrm{BLV}^{-}$cattle, PBMC were cultivated for 24,48 , and $72 \mathrm{~h}$ at $37^{\circ} \mathrm{C}$ with $5 \% \mathrm{CO}_{2}$ in RPMI-1640 in the presence of pokeweed mitogen (PWM, $5 \mu \mathrm{g} / \mathrm{mL}$, Sigma-Aldrich) or phorbol 12 -myristate acetate (PMA) and ionomycin $(20 \mathrm{ng} / \mathrm{mL}$ and $1 \mu \mathrm{g} / \mathrm{mL}$; Sigma-Aldrich). No fewer than 13000 lymphocytes and no more than 36000 lymphocytes were analyzed among the samples.

\section{Analysis of PD-L1 expression in BLV-gp51 positive cells}

To confirm PD-L1 expression in $\mathrm{BLV}^{+}$cells, intracellular staining was performed. PBMC isolated from $\mathrm{BLV}^{+}$or $\mathrm{BLV}^{-}$cattle were cultivated for $18 \mathrm{~h}$, and the cells were stained by anti-human PD-L1 (Santa Cruz Biotechnology, CA, USA) and anti-bovine IgM as previously described [19]. After surface staining, the cells were fixed and permealized by FOXP3 Fix/Perm kit (BioLegend, Cambridge, UK) according to the manufacturer's protocol. Then, the cells were stained with anti-gp51 (BLV1; VMRD) pre-labeled with Zenon PE, washed and immediately analyzed. More than 30000 lymphocytes were analyzed.

\section{PD-1 blockade assay}

To determine the effect of the immune activation by anti-PD-1 mAb, bovine PBMC were cultured with $20 \mu \mathrm{g} / \mathrm{mL}$ of anti-PD-1 mAb or rat IgG (Sigma-Aldrich) 


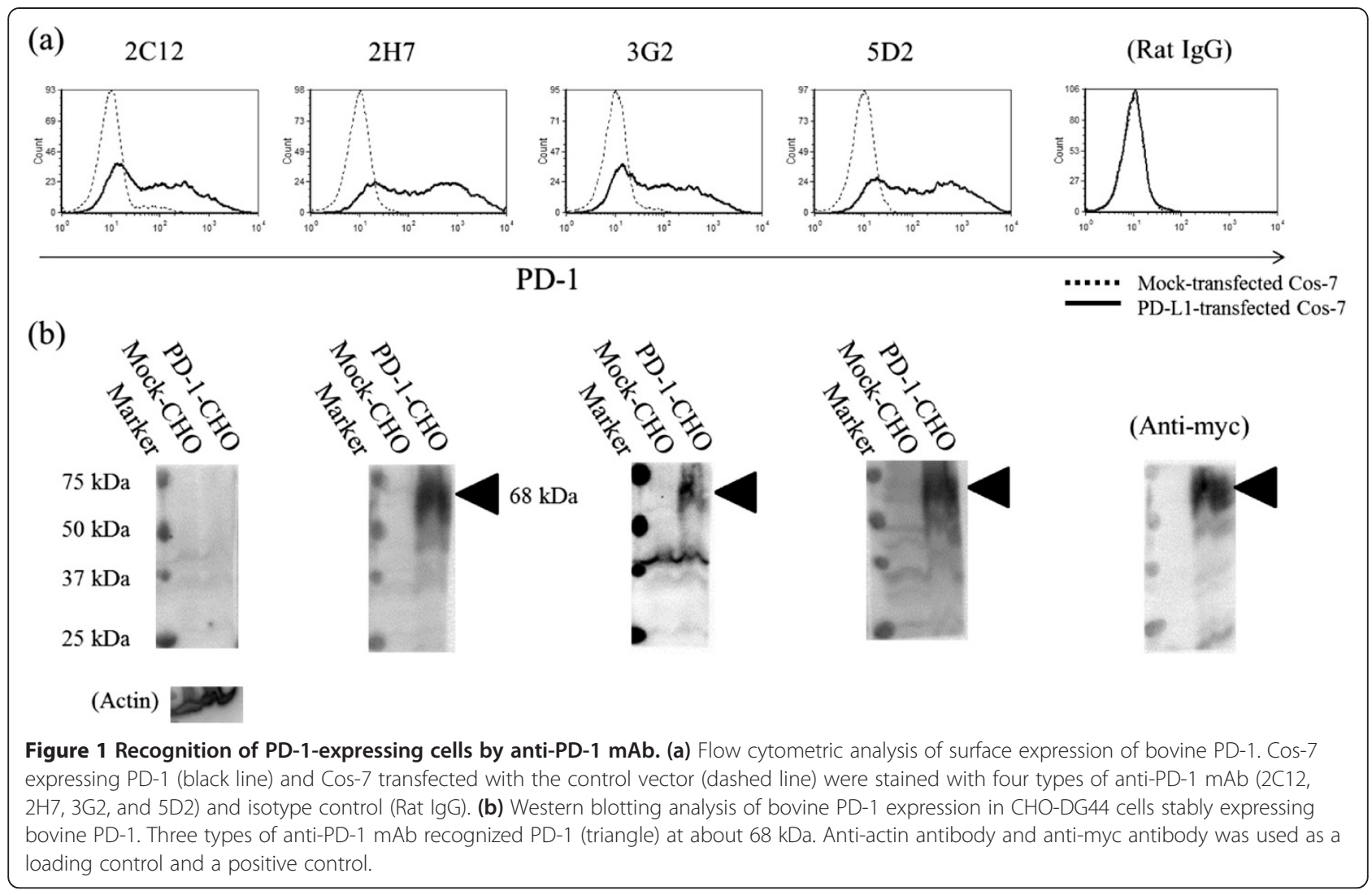

in the presence or absence of PMA/ionomycin or in the presence of $10 \mu \mathrm{g} / \mathrm{mL}$ BLV-gp51 peptide mixture (15 mer). The peptide mixture covering the entire length of gp51 and overlapping by 11 amino acids, were synthesized in Hokkaido System Science (Hokkaido, Japan). Flag peptide (DYKDDDDK) was used as the negative control for gp51 peptide mixture. After 2 days, the cells were collected for detection of apoptosis and expression analysis of gp51, WC4 and CD80. The supernatants were harvested and analyzed by ELISA. For real-time PCR or cell proliferation assay, cultivated cells were collected after 1 day or 5 days. In a portion of experiments, isolated B cells from PBMC were cultured. PBMC were incubated with anti-bovine IgM, and $\operatorname{IgM}^{+}$ $B$ cells were isolated by autoMACS Pro and anti-mouse IgG1 MicroBeads (Miltenyi Biotec).

\section{IFN- $\gamma$ and IL-10 ELISA}

The production of IFN- $\gamma$ in supernatants was measured by ELISA for bovine IFN- $\gamma$ (Mabtech, Nacka Strand, Sweden) according to the manufacturer's protocol. The results were calculated based on a standard curve ranging from $7.8 \mathrm{pg} / \mathrm{mL}$ to $500 \mathrm{pg} / \mathrm{mL}$. Sandwich ELISA of IL-10 was performed with two antibodies; anti-IL-10 (CC318; AbD Serotec) as capture antibody and biotinconjugated anti-IL-10 (CC320; AbD Serotec) as the detective antibody. Briefly, 96 well plates were coated overnight with CC318 diluted with PBS. After washing with PBS and blocking by PBS-T containing $0.1 \%$ bovine serum albumin (Sigma-Aldrich), the samples were incubated in the wells for $2 \mathrm{~h}$. Following washing, diluted detective antibodies (CC320) were added to the wells and incubated for $1 \mathrm{~h}$. After further washing, Neutra-Avidin -HRP was added and incubated for $1 \mathrm{~h}$. Finally, the plates were washed and incubated with TMB One Component Substrate (Bethyl Laboratories, TX, USA), and absorbance was measured by MTP-650FA (Corona Electric, Ibaraki, Japan). A standard curve was constructed using plasma which was separated from a cattle-derived blood stimulated with $10 \mu \mathrm{g} / \mathrm{mL}$ concanavalin A (SigmaAldrich) and $10 \mu \mathrm{g} / \mathrm{mL}$ lipopolysaccharide (Sigma-Aldrich) for $48 \mathrm{~h}$. The 1 (64) arb. unit is defined in terms of the amount of IL-10 in 15.625 (1000) $\mu \mathrm{L}$ of the stimulated plasma. Reported values represent the mean of duplicate samples.

\section{Cell proliferation assay}

To investigate the effect of PD-1 blockade on the proliferation of PBMC, a CFSE proliferation assay was performed. In summary, PBMC were incubated with $2 \mu \mathrm{M}$ CFSE (Life technologies) diluted with PBS at $37^{\circ} \mathrm{C}$ for $15 \mathrm{~min}$, washed with RPMI-1640 three times and cultured for 5 days. Then, the cells were stained with anti-IgM pre-labeled with Lightning-Link PE-Cy7 and 
(a)

(b)
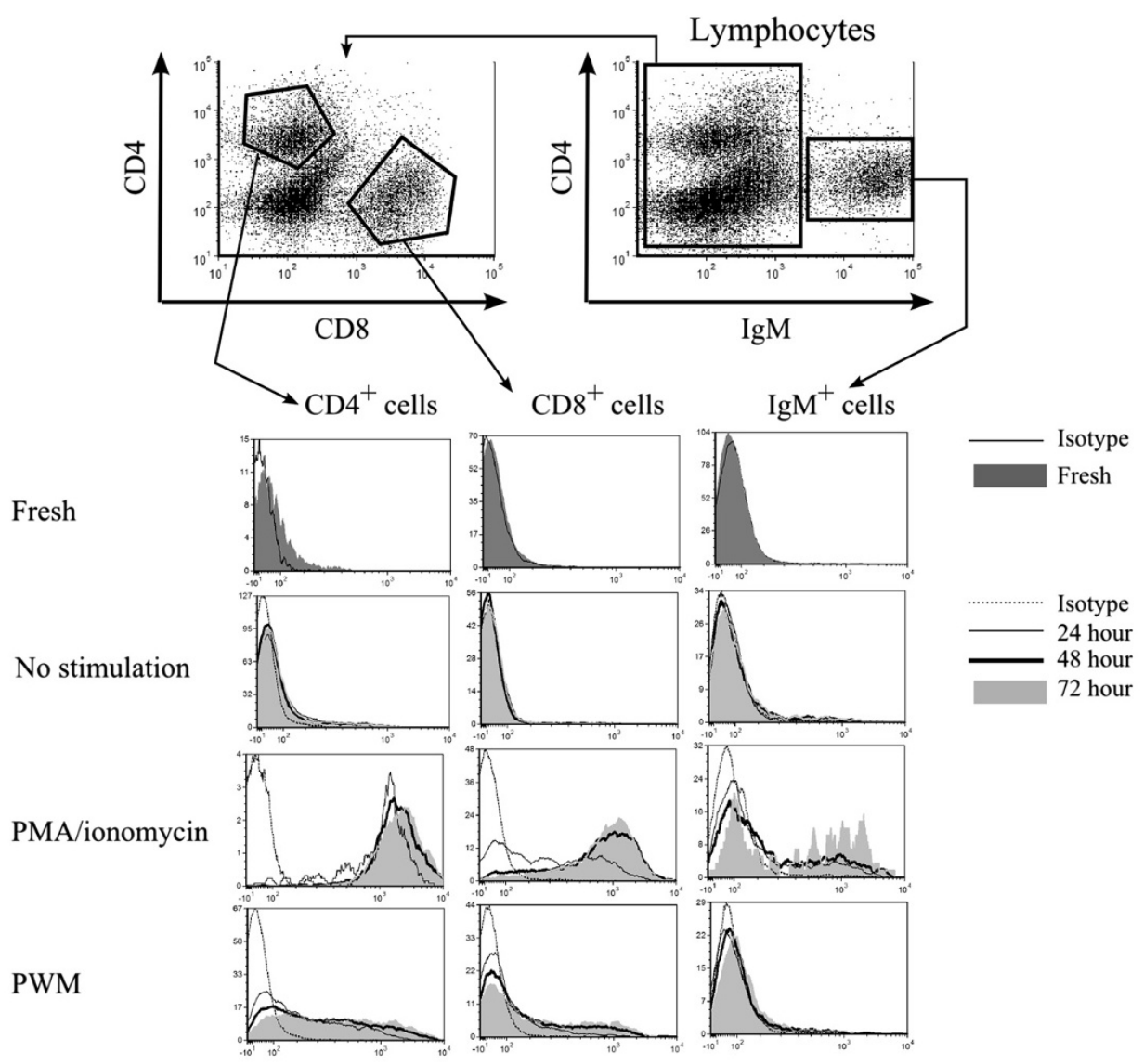

(c)
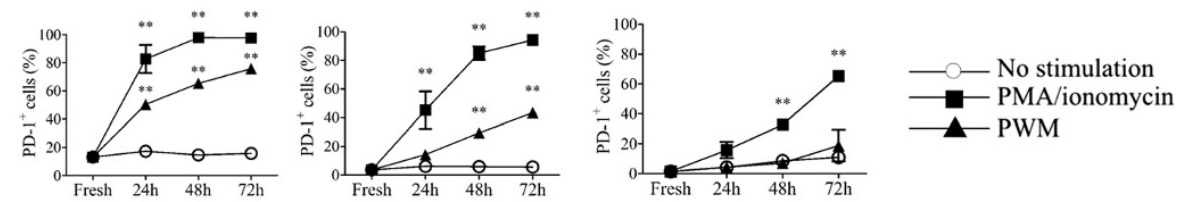

(d)

No stimulation
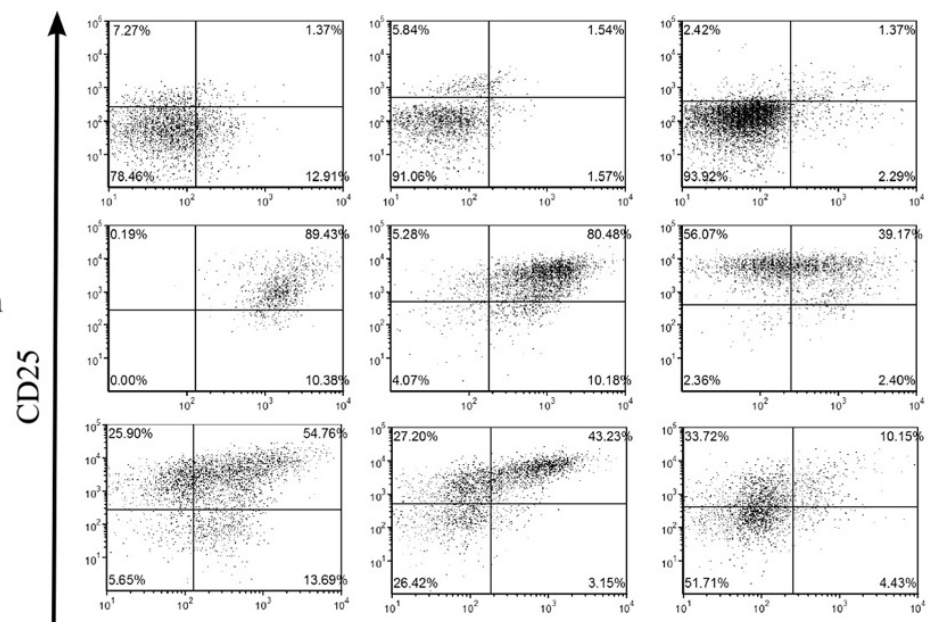

PMA/ionomycin

PWM

PD-1

Figure 2 (See legend on next page.) 
(See figure on previous page.)

Figure 2 Recognition of PD-1-expressing lymphocytes by anti-PD-1 mAb. (a) Gating strategies for $C D 4^{+} T$ cells, $C D 8^{+} T$ cells and lgM ${ }^{+} B$ cells in bovine lymphocytes. (b) Representative histograms obtained by flow cytometry of PD-1 expression in $C D 4^{+} \mathrm{T}$ cells, $C D 8^{+} \mathrm{T}$ cells and lgM ${ }^{+}$ $B$ cells isolated from three BLV cattle. Freshly isolated PBMC were stained with anti-PD-1 (5D2), CD4, CD8, and IgM Ab. PBMC were cultivated with PBS (No stimulation), PMA/ionomycin, and PWM for 24, 48, and $72 \mathrm{~h}$, and stained in a similar way. (c) Proportions of PD-1 positive cells in $\mathrm{CD}^{+} \mathrm{T}$ cells, CD8 ${ }^{+} \mathrm{T}$ cells and $\mathrm{IgM}^{+} \mathrm{B}$ cells. Statistical comparisons between percentages of PD-1 positive cells stimulated with PBS and PMA/ ionomycin or PWM were made using two way ANOVA. Differences were considered statistically significant at $P<0.05$ (** $P<0.01$ ). (d) Representative dot plots of PD-1 and CD25 expression in CD4 $4^{+} \mathrm{T}$ cells, CD8 ${ }^{+} \mathrm{T}$ cells and $\operatorname{lgM}^{+} \mathrm{B}$ cells $48 \mathrm{~h}$ after cultivation.

analyzed immediately by flow cytometry. Percentages of $\mathrm{CFSE}^{\mathrm{lo}} \mathrm{IgM}^{-}$lymphocytes were measured for evaluation of the proliferation of lymphocytes other than B cells. No fewer than 2500 and no more than 14000 lymphocytes other than B cells were analyzed among the samples.

\section{Expression analysis of BLV-gp51, WC4 and CD80}

To analyze the effect of PD-1 blockade on B cell function, cultivated PBMC were stained with anti-IgM prelabeled with Zenon Alexa Fluor 488 and anti-WC4 or anti-CD80 (AbD Serotec) or anti-BLV-gp51. Alexa Fluor 647-conjugated anti-mouse IgG was used for anti-WC4 and anti-CD80 as a secondary antibody. BLV-gp51 staining of either PBMC or isolated B cells was performed as described above. Appropriate isotype controls were performed with each sample. More than 20000 lymphocytes were analyzed.

\section{Real-time PCR}

Total RNA was extracted from cultivated PBMC by RNeasy Plus Mini Kit (QIAGEN, CA, USA), and cDNA was synthesized by Reverse Transcriptase M-MLV (Takara) following the manufacturer's instructions. Quantitative RT real-time PCR was performed using the LightCycler 480 system II (Roche Diagnostics, Mannheim, Germany) according to the manufacturer's instructions. Primers used for the amplification of $B A F F$ cDNA were 5'- CCA AGC TGG AGG AAG GAG ATG AAC TC-3' and 5'- CTC CAT CTC GGG ATA TCT TAG CAT C-3'. The amount of BAFF mRNA expression was divided by the expression of GAPDH and $\beta$-actin mRNA as internal control genes. Each amplification procedure was done in duplicate, and the results were indicated as relative change to control (no antibody treatment).

\section{Detection of apoptosis}

To detect apoptotic B cells, cultivated PBMC were stained with anti-IgM as a first antibody and Alexa Fluor 647-conjugated anti-mouse IgG as a secondary antibody. Following washing, cells were incubated with Annexin V-FITC (Beckman Coulter) for $15 \mathrm{~min}$ and added 7AAD (BD Biosciences). No fewer than 12000 lymphocytes and no more than 20000 lymphocytes were analyzed among samples. The results are presented as percentages of $\mathrm{FITC}^{+} 7$-AAD cells in total $\operatorname{IgM}^{+} \mathrm{B}$ cells.

\section{Statistical analysis}

The Spearman rank-correlation, one-way ANOVA with Tukey's post test, two-way ANOVA and Wilcoxon matched pairs test were performed using GraphPad Prism version 5.0. $P$ values $<0.05$ were considered statistically significant.

\section{Results}

\section{Anti-PD-1 mAb react with PD-1-expressing cells}

Supernatants containing antibody from 576 hybridoma colonies were screened for their binding to bovine IgG and PD-1-Ig by ELISA. Hybridomas that produced mAb-recognizing bovine IgG were excluded. Four hybridomas (2C12, 2H7, 3G2, and 5D2) were cloned and confirmed as clones producing $\mathrm{mAb}$ that reacted with Cos-7 expressing PD-1 but not with cells transfected with the control vector (Table 1 and Figure 1a). Control antibody (Rat IgG) did not react with both of the cells. The degree of fluorescent signals of $2 \mathrm{H} 7$ and 5D2 were different from those of $2 \mathrm{C} 12$ and 3G2. Anti-PD-1 mAb, except for $2 \mathrm{C} 12$, were able to recognize heat-denatured PD-1 at approximately $68 \mathrm{kDa}$ by Western blotting, showing that $2 \mathrm{C} 12$ could recognize a conformational epitope of bovine PD-1 (Figure 1b).

\section{Anti-PD-1 mAb react with bovine lymphocytes}

To confirm that anti-PD-1 mAb can recognize bovine PD-1 naturally expressed on bovine lymphocytes, we examined surface PD-1 expression on $\mathrm{CD}^{+}$and $\mathrm{CD}^{+} \mathrm{T}$ cells as well as $\operatorname{IgM}^{+} \mathrm{B}$ cells freshly isolated or stimulated by mitogens, such as PWM and PMA/ionomycin in vitro. An example of the gating strategy is shown in Figure $2 \mathrm{a} . \operatorname{IgM}^{+} \mathrm{B}$ cells were first gated and $\operatorname{IgM}^{-}$cells further analyzed for CD4 and CD8 expression. Amongst the four anti-PD-1 mAb, the strongest fluorescence was observed in PBMC stained with 5D2 (data not shown); therefore, the cells were stained with $5 \mathrm{D} 2$ for subsequent expression analyses of bovine PD-1. PD-1 was expressed mainly on $\mathrm{CD}^{+} \mathrm{T}$ cells from freshly isolated PBMC, whereas $\mathrm{CD}^{+} \mathrm{T}$ cells and B cells barely expressed PD-1 (Figure 2b). 


Table $\mathbf{1}$ The number of positive hybridomas in each
screening test
\begin{tabular}{lccc}
\hline $\begin{array}{c}\text { ELISA for } \\
\text { PD-1-lg }\end{array}$ & $\begin{array}{c}\text { ELISA for } \\
\text { bovine IgG }\end{array}$ & $\begin{array}{c}\text { ELISA for PD-1-lg } \\
\text { (did not recognize } \\
\text { bovine lgG) }\end{array}$ & $\begin{array}{c}\text { FACS for PD-1 } \\
\text { expressing } \\
\text { Cos-7 }\end{array}$ \\
\hline 47 & 78 & 14 & 4
\end{tabular}

When PBMC were cultivated in the presence of mitogen, PD-1 expression in lymphocytes was elevated, whereas in vitro incubation without any stimulant did not affect PD-1 expression in any population of lymphocytes (Figure 2b, c). PMA/ionomycin stimulation more quickly induced PD-1 expression than in the case of no stimulant, which was strongly enhanced in more than $90 \%$ of $\mathrm{CD}^{+}$and $\mathrm{CD}^{+}{ }^{+}$cells and half of B cells at $72 \mathrm{~h}$ (Figure 2b). Although PWM stimulates both $\mathrm{T}$ and B cells [25] like PMA/ionomycin, on one level or another, subsets of $\mathrm{CD} 4^{+}$and $\mathrm{CD} 8^{+} \mathrm{T}$ cells stimulated by PWM expressed less PD-1 antigen than PBMC treated with PMA/ionomycin at the same point in time, and the rate of the upregulation in PWM stimulation was also slower. Furthermore, upregulation of PD-1 expression on B cells was not induced by PWM stimulation. In the case of any stimulation, $\mathrm{CD} 4^{+} \mathrm{T}$ cells were prone to more quickly upregulate $\mathrm{PD}-1$ expression than $\mathrm{CD} 8^{+} \mathrm{T}$ cells and B cells.

A previous report revealed that activated lymphocytes express PD-1 antigen in mice [26]; therefore bovine PD1 expression on stimulated lymphocytes detected by a classical activation marker, CD25, was evaluated. Fortyeight hours after PMA/ionomycin stimulation, CD25 expression was strongly upregulated in either $\mathrm{CD}^{+}$and $\mathrm{CD}^{+} \mathrm{T}$ cells and $\mathrm{IgM}^{+} \mathrm{B}$ cells, and almost all $\mathrm{T}$ cells and subset of $B$ cells expressed PD-1 (Figure 2d). Otherwise, under PWM stimulation, CD25 expression varied widely among the subsets. Moreover, $\mathrm{CD}_{4}^{+} \mathrm{CD} 25^{-} \mathrm{T}$ cells expressed PD-1, but $\mathrm{CD}^{+} \mathrm{CD}^{-} 5^{-} \mathrm{T}$ cells barely did. We examined PD-1 expression in PBMC isolated from three healthy cattle and similar results were obtained in each case.

\section{Anti-PD-1 mAb activate IFN- $\gamma$ production}

To clarify the function of mAb that inhibit the PD-1 /PD-L1 pathway and the inhibitory signal from PD-1, we performed a PD-1 blockade assay. PBMC isolated from $\mathrm{BLV}^{-}$cattle were cultured for $48 \mathrm{~h}$ in the presence of each anti-PD-1 mAb or control antibody, and IFN- $\gamma$ production was then measured in the supernatants using ELISA. All of the four anti-PD-1 mAb significantly increased IFN- $\gamma$ production in PBMC in comparison to those treated with control rat IgG (Figure 3a). The treatments of $2 \mathrm{H} 7$ and 5D2 upregulated the production of
IFN- $\gamma$ in all sample cases. Furthermore, in PBMC cultivated with $\mathrm{PMA} /$ ionomycin in vitro, $2 \mathrm{C} 12$ and $5 \mathrm{D} 2$, but not $2 \mathrm{H} 7$ and $3 \mathrm{G} 2$, significantly enhanced IFN- $\gamma$ production (Figure $3 b$ ), showing that the function of activated lymphocytes by PMA/ionomycin stimulation could be additionally enhanced by PD-1 blockade with $2 \mathrm{C} 12$ or 5D2 treatment. The most effective mAb was not determined because there were individual differences in INF$\gamma$ production, and no significant difference was observed within the degree of enhancement of IFN- $\gamma$ production induced by the treatment with the four mAb.

\section{PD-1 expression is upregulated in $\mathrm{CD}^{+}$and $\mathrm{CD}^{+}{ }^{+} \mathrm{T}$ cells in $\mathrm{BLV}^{+}$cattle with lymphoma}

Our previous reports claimed that $P D-1$ mRNA expression in T cells isolated from BCBL was higher than from $\mathrm{BLV}^{-}$cattle [20]. To confirm the PD-1 expression on the cell surface of $\mathrm{T}$ cells in $\mathrm{BLV}^{+}$cattle, flow cytometric analysis was performed in PBMC and mesenteric (BLV ${ }^{-}$ and $\mathrm{BLV}^{+}$cattle) or tumor-bearing (BCBL) LN cells using anti-PD-1 mAb, 5D2. In blood, the mean percentages of PD- $1^{+} \mathrm{CD}^{+} \mathrm{T}$ cells were higher in cattle with lymphoma than in $\mathrm{BLV}^{+}$and $\mathrm{BLV}^{-}$cattle (Figure 4a). Meanwhile, in LN cells, the rates of PD-1 expression in both $\mathrm{CD} 4^{+}$and $\mathrm{CD} 8^{+} \mathrm{T}$ cells were significantly higher in $\mathrm{BCBL}$ than in $\mathrm{BLV}^{+}$and $\mathrm{BLV}^{-}$cattle (Figure $4 \mathrm{~b}$; an example of the gating strategy is shown in Figure 4c). $\operatorname{IgM}^{+} \mathrm{B}$ cells in all samples barely showed PD-1 expression (data not shown), although $\mathrm{CD} 19^{+} \mathrm{B}$ cells in human patients of chronic lymphocytic leukemia strongly expressed PD-1 [27].

PD-L1 expression analysis in BLV infection had been performed in our previous report [19]. However, the question remained whether $\mathrm{BLV}^{+} \mathrm{B}$ cells actually express PD-L1 or not. To activate the expression of the BLV protein, such as gp51 and to permit detection of the $\mathrm{BLV}^{+} \mathrm{B}$ cells, PBMC were cultivated overnight before cell staining. BLV-gp51 expression was not detected in freshly isolated B cells, cultivation of PBMC overnight resulted in reactivation of gp51 expression (see Additional file 1) in line with previous findings [28-30]. The PD-L1 expression was able to be detected in gp $51^{+}$ $B$ cells (Figure $4 \mathrm{~d}$ ). There is no difference in percentages of PD-L1 expression between gp $51^{+}$and gp $51^{-}$B cells in $\mathrm{BLV}^{+}$cattle. The mean percentages of $\mathrm{PD}-\mathrm{L}^{+}$cells in $\mathrm{B}$ cells from $\mathrm{BLV}^{+}$cattle were higher compared to those from $\mathrm{BLV}^{-}$cattle, as described in a previous report [19].

\section{PD-1 blockade upregulates T-cell function in PBMC from $\mathrm{BLV}^{+}$cattle}

To assess whether PD-1 blockade activates T-cell function in response to $\mathrm{BLV}$ antigen, $\mathrm{PBMC}$ from $\mathrm{BLV}^{+}$cattle were cultured with BLV-gp51 peptide mixture in the presence or absence of anti-PD-1 mAb (5D2), and IFN- $\gamma$ 
production and proliferation of lymphocytes were measured. The IFN- $\gamma$ production in PBMC was upregulated by gp51 peptide mixture relative to Flag peptide (Figure 5a and Additional file 2), indicating that the anti-gp51 immune reaction was induced by gp51 peptide mixture. As expected, PD-1 blockade additionally enhanced IFN- $\gamma$ production in the presence of a gp51 peptide mix, as compared to the treatment with rat IgG (Figure $5 \mathrm{~b}$ ). The increasing rate of IFN- $\gamma$ production in PD-1 blockade was correlated with frequencies of PD1 expression in $\mathrm{CD}^{+}{ }^{+} \mathrm{T}$ cells (Figure $5 \mathrm{c}$ ), but not $\mathrm{CD}^{+}$ $\mathrm{T}$ cells (data not shown). On the contrary, one of the immunoinhibitory cytokines, IL-10 production was not altered by PD-1 blockade (Figure $5 \mathrm{~d}$ ). Next, proliferation of lymphocytes was analyzed by CFSE staining. Detection of proliferating $\mathrm{T}$ cells was difficult because there were very few $\mathrm{T}$ cells in cultivated PBMC from BLVinfected cattle causing abnormal B cell proliferation. So, the proliferation of lymphocytes other than B cells was investigated using the gating strategies described in Figure 1a and 2c. PD-1 blockade in PBMC resulted in an increase in the frequencies of $\mathrm{CFSE}^{\mathrm{lo}} \mathrm{IgM}^{-}$lymphocytes relative to the treatment of control antibody (Figure 5e).

\section{PD-1 blockade inhibits BLV-gp51 expression and B cell activation}

Next, we evaluated whether PD-1 blockade altered Bcell activation and BLV expression. The incubation of PBMC with gp51 peptide mix in the presence of antiPD-1 mAb resulted in the reduction of the frequencies of gp51 ${ }^{+}$cells in $\operatorname{IgM}^{+}$B cells (Figure 6a). Because previous reports showed that $\mathrm{B}$ cell activation augments viral expression ex vivo [31], we hypothesized that one of the mechanisms responsible for the inhibition of gp51 expression resulting from PD-1 blockade was downregulation of $\mathrm{B}$ cell activation. To test this hypothesis, the expression of activation markers, WC4 (CD19 like molecule) and CD80, of B cells were measured. PD1 blockade resulted in the attenuation of WC4 and CD80 expression in B cells (Figure 6b, c), and, moreover, reduction in the expression of $B A F F$ mRNA (Figure 6d), which is an important cytokine for B cell survival [32].

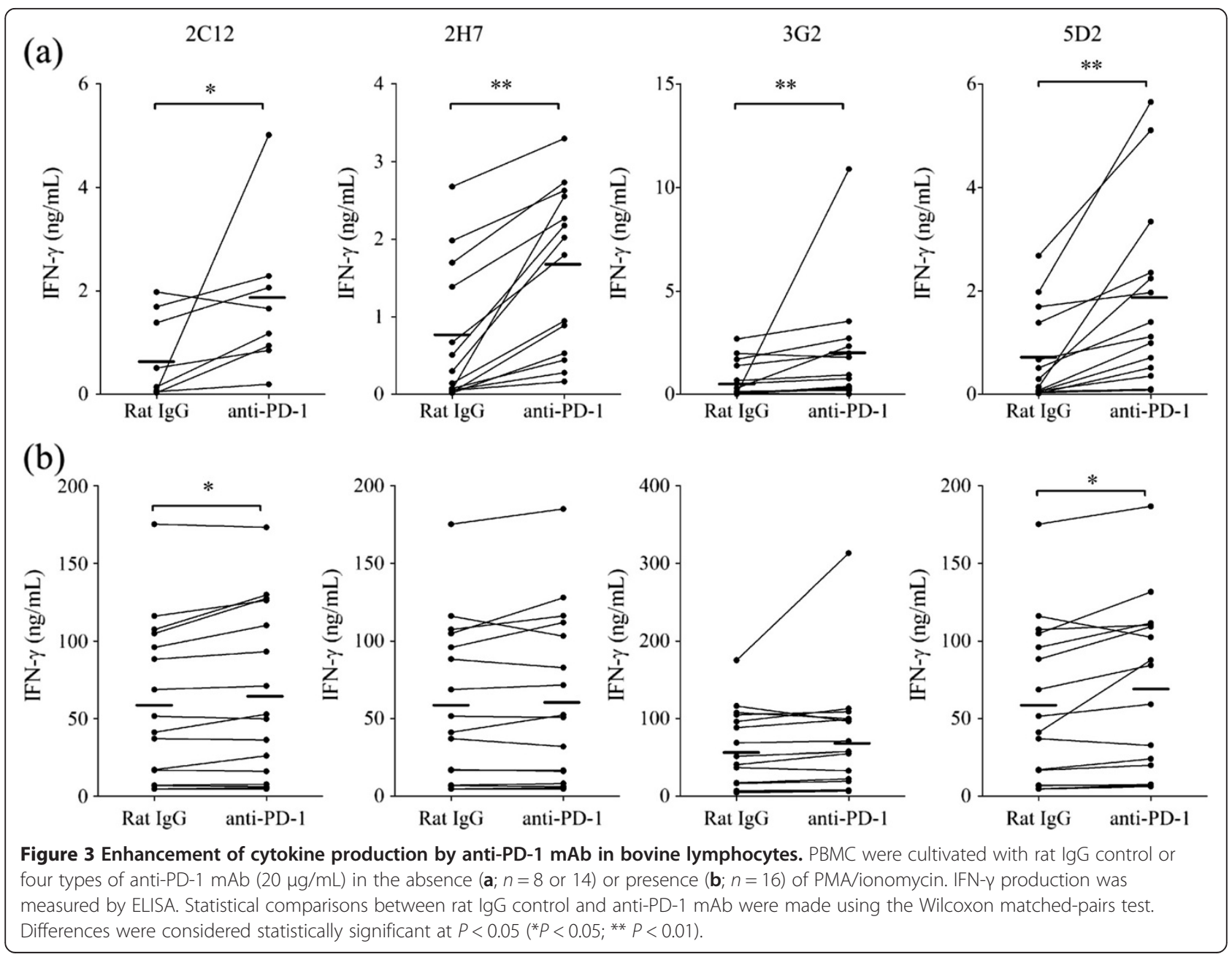




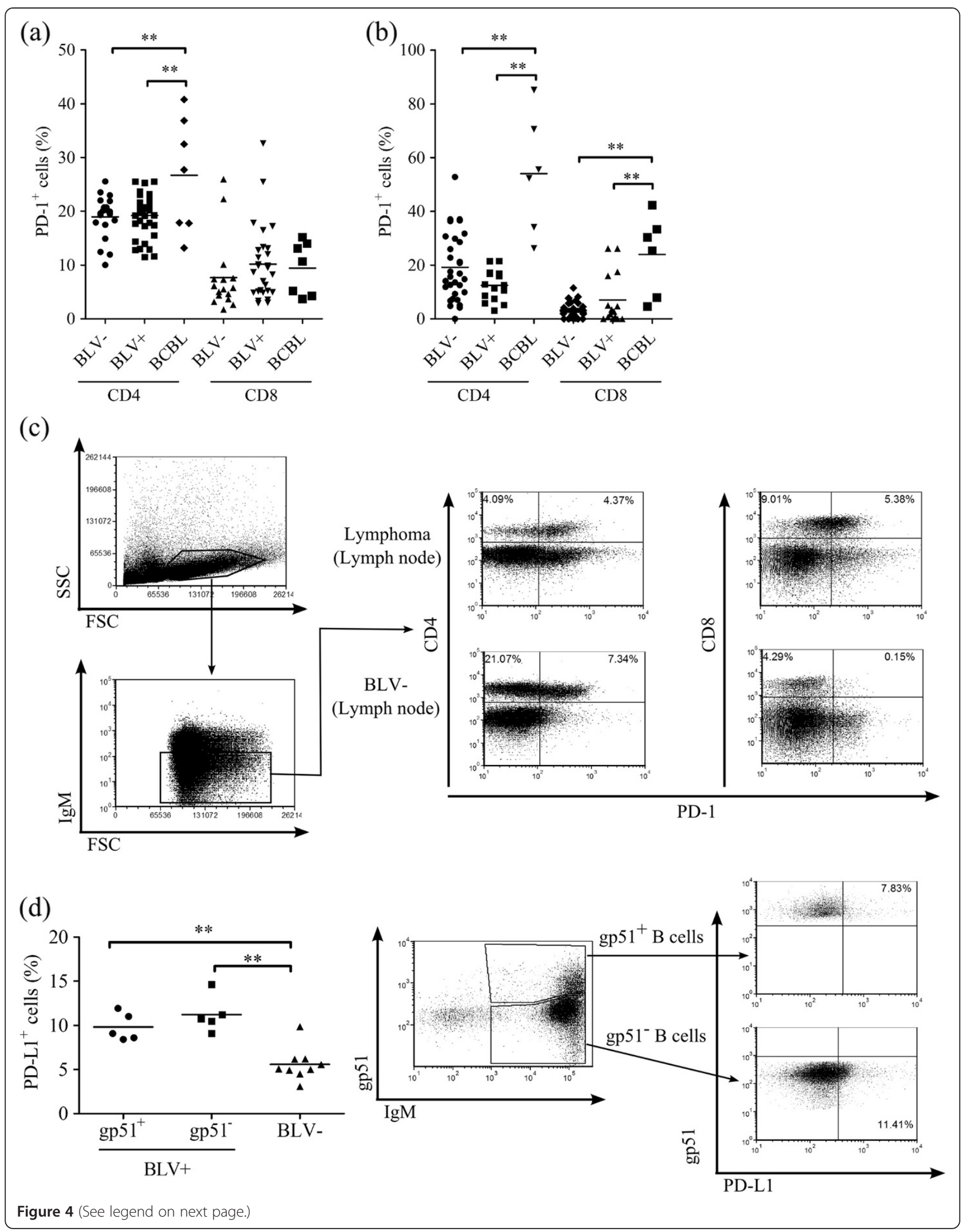


(See figure on previous page.)

Figure 4 Expression analysis of bovine PD-1 in BLV-infected cattle. (a, b) Percentages of PD-1-expressing CD4 ${ }^{+}$and $C D 8^{+} \mathrm{T}$ cells in PBMC (a) and LN (b) isolated from BLV cattle (CD4 ${ }^{+} \mathrm{T}$ cells; $n=20$ and $31, \mathrm{CD}^{+} \mathrm{T}$ cells; $n=16$ and 31$), \mathrm{BLV}^{+}$cattle $\left(\mathrm{CD} 4^{+} \mathrm{T}\right.$ cells; $n=35$ and $15, \mathrm{CD} 8^{+}$ T cells; $n=28$ and 15) and BCBL (CD4 ${ }^{+}$T cells; $n=7$ and $6, \mathrm{CD}^{+} \mathrm{T}$ cells; $n=7$ and 6$)$. (c) An example of gating strategies for PD- 1 expression in $\mathrm{CD}^{+} \mathrm{T}$ cells and $\mathrm{CD} 8^{+} \mathrm{T}$ cells isolated from lymph node of BCBL and BLV cattle. Values in the quadrant indicate the percentage of the cells in

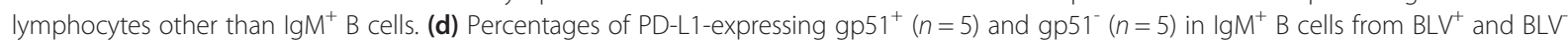
cattle $(n=9)$. Representative dot plots of PD-L1 staining in gp51 $1^{+}$or gp51- B cells are also shown. Statistical comparisons were made using one-way ANOVA with Tukey's test. Differences were considered statistically significant at $P<0.05$ (** $P<0.01)$.

Moreover, the frequencies of apoptotic B cells were also increased in PBMC treated with anti-PD-1 mAb, as compared with control antibody (Figure 6e). Finally, to assess whether PD-1 blockade has a direct effect on B cells, isolated B cells were cultivated with gp51 peptide mix in the presence of anti-PD- $1 \mathrm{mAb}$. As expected, the significant changes in gp51 expression in B cells by the PD-1 blockade were not observed (Figure 6f), suggesting that anti-PD-1 mAb did not directly affect gp51 expression in B cells.

\section{Discussion}

PD-1 on lymphocytes is thought to be a major immunoinhibitory receptor involved in the maintenance of peripheral immune tolerance and immune evasion of tumors and infectious agents [2]. The expression of $P D$ 1 mRNA was previously analyzed in some animal species by real-time PCR because of lack of specific antibodies $[17,20]$. However, although the real-time PCR method can be used for quantitative analysis, the method targeting PD-1 requires attention because several splice variants and homologs of the human and mouse $P D-1$ gene have been reported [33-35]. PD-1 mRNA transcripts, in which the third exon of the $P D-1$ gene encoding the transmembrane domain was spliced out, encoded a soluble form of PD-1 (sPD-1) [33], and sPD-1 blocked the immunoinhibitory effect of PD-1 expressed on the $\mathrm{T}$ cell membrane [34]. Thus, the primer set must be designed carefully to amplify only the membrane-bound form but not the soluble form or other splice variants of PD-1 mRNA. Expression analysis of membrane-bound PD1 antigen by flow cytometry is essential to investigate the exact immunoinhibitory effect of PD-1 in immune cells. In this report, we describe the establishment of anti-bovine $\mathrm{PD}-1 \mathrm{mAb}$ and confirmed the increased frequency of PD$1^{+} \mathrm{T}$ cells in BCBL. We also confirmed the upregulation of IFN- $\gamma$ production and proliferation and the inhibition of BLV-gp51 expression and B-cell activation in PBMC from $\mathrm{BLV}^{+}$cattle by the treatment with anti-PD-1 mAb.

The molecular weight of both human and bovine PD1 was expected to be approximately $30 \mathrm{kDa}$ by calculation from their amino acid sequences. However, the band of human PD-1 was found at about $55 \mathrm{kDa}$ in western blotting [26]. Also, in this study, bovine PD-1 was detected at about $68 \mathrm{kDa}$. From these observations, human PD-1 and bovine PD-1 are thought to be heavily glycosylated, which is consistent with the potential $N$ glycosylation sites of human and bovine PD-1.

$\mathrm{CD}^{+}$and $\mathrm{CD}^{+} \mathrm{T}$ cells are the main targets of study when investigating immunoinhibition induced by PD-1 in human and mouse models. In cattle, CD4 ${ }^{+} \mathrm{T}$ cells were the main cells that express PD-1 in freshly isolated PBMC, but the expression levels were not so high. In humans and mice, PD-1 expression levels in total $\mathrm{CD}_{4}^{+}$ and $\mathrm{CD}^{+} \mathrm{T}$ cells are also very low, even when detected by sensitive instruments, such as flow cytometry [26,36]. $\mathrm{T}$ cells are divided into naive and different memory subsets by the expression of CD45RO, CD45RA and CCR7, and the memory $\mathrm{T}$ cells express high levels of PD-1 [7]. In this study, PD-1 expression in total $\mathrm{T}$ cells or $\mathrm{B}$ cells was investigated, but detailed expression analysis is needed using many cell markers for clarification whether PD $-1^{+} \mathrm{CD}^{+} \mathrm{T}$ cells are the memory $\mathrm{T}$ cells or other phenotype.

Stimulation by PMA/ionomycin strongly enhanced PD- 1 expression in $\mathrm{CD}^{+}$and $\mathrm{CD}^{+} \mathrm{T}$ cells and $\mathrm{B}$ cells. These findings agree with previous reports, which indicated that activated $\mathrm{T}$ and $\mathrm{B}$ cells express PD-1 antigen [26], perhaps, for the sake of preventing activationinduced cell death. CD25 is the part of IL-2 receptor and identified as the classical activation marker. We hypothesized that PD-1 upregulation occurred in stimulated lymphocytes which was detected by CD25 expression. However, the data revealed that $\mathrm{CD} 4^{+} \mathrm{CD} 25^{-}$ T cells also expressed PD- 1 and not all $\mathrm{CD} 8^{+} \mathrm{CD} 25^{+} \mathrm{T}$ cells and $\operatorname{IgM}^{+} \mathrm{CD} 25^{+} \mathrm{B}$ cells expressed it $48 \mathrm{~h}$ after the stimulation, suggesting that the cell activation detected by CD25 was not the single cause of PD-1 upregulation. More work is needed to clarify the kinetics of induction of PD-1 expression in each cell population.

In chronic infection or tumors, production of inflammatory cytokines and proliferation in response to antigens by pathogen-specific $\mathrm{CD}^{+}$or $\mathrm{CD}^{+} \mathrm{T}$ cells were impaired by the PD-1/PD-L1 pathway. These $\mathrm{T}$ cells failed to eradicate the infected cells or cancer cells, and PD-1 was the most appropriate marker of these "exhausted" T cells $[9,21]$. In this report, BLV infection was chosen as a typical chronic infection and tumor in cattle for PD-1 expression and functional analysis. BLV and HTLV-1 are related deltaretroviruses, and higher 


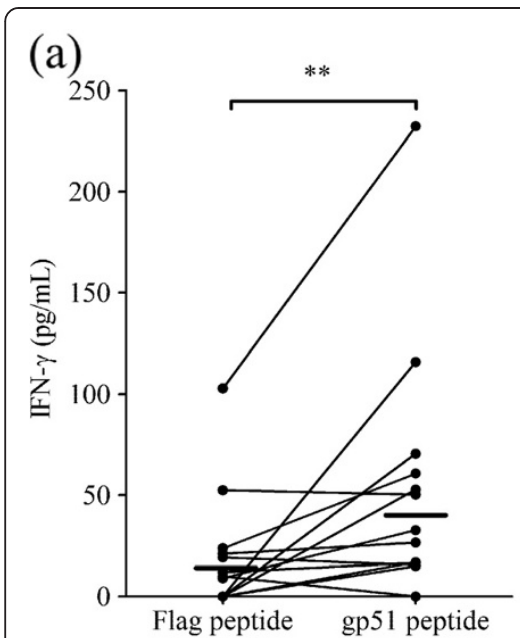

(d)

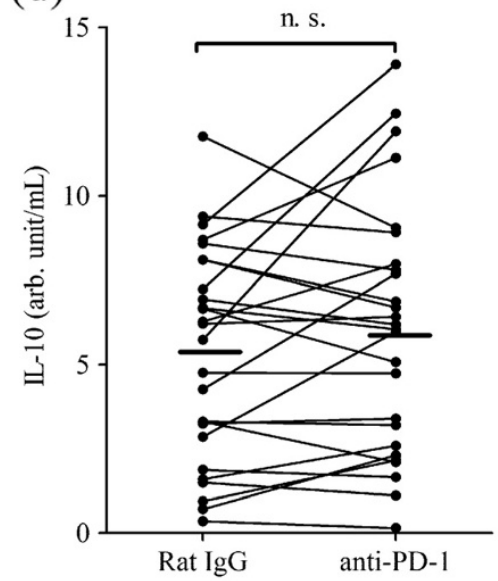

(b)

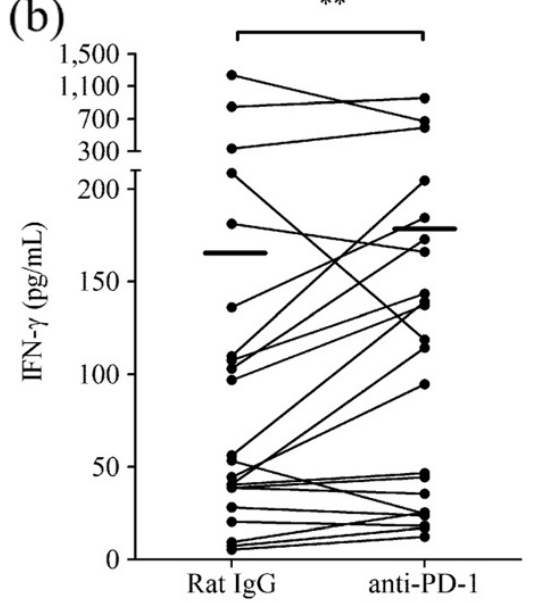

(e)

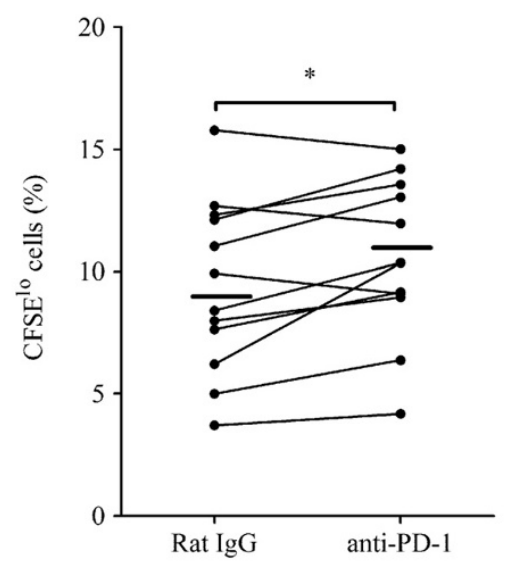

(c)

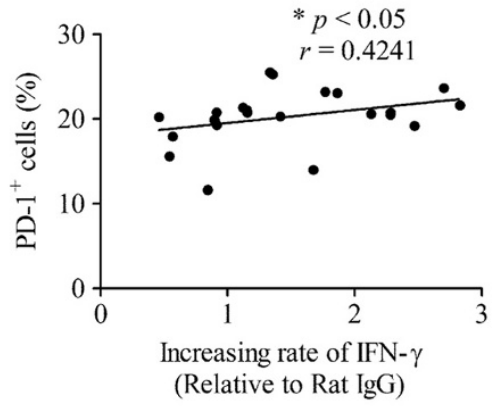

Rat IgG

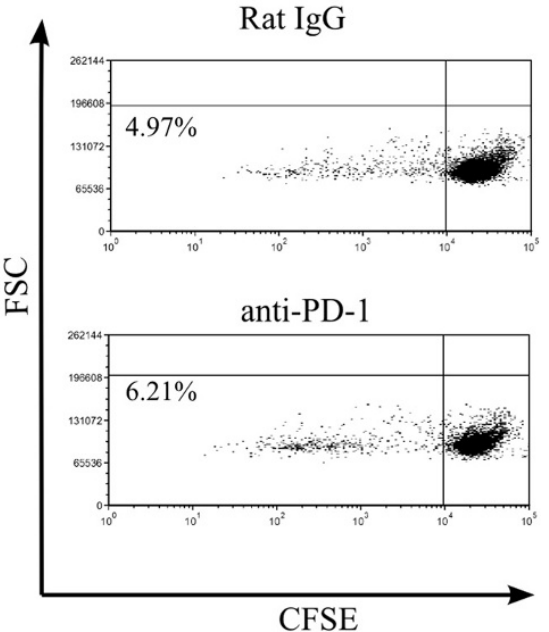

Figure 5 Effect of PD-1 blockade on T-cell function. (a) PBMC from BLV ${ }^{+}$cattle were cultured with Flag peptide as negative control and gp51

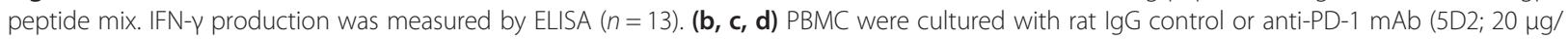
$\mathrm{mL})$ in the presence of gp51 peptide mix. IFN- $\gamma$ and IL-10 production was measured by ELISA (b; $n=22, d ; n=26)$. Positive correlation between increasing rate of IFN- $y$ production and percentages of PD-1 $1^{+}$cells in $\mathrm{CD}^{+} \mathrm{T}$ cells corresponding to Figure $4 \mathrm{a}$ ( $\left.\mathbf{c} ; n=22\right)$. Correlation statistics were analyzed using the Spearman correlation. (e) The proliferative responses were evaluated by detection of CFSE ${ }^{\text {lo }}$ cells in lgM- lymphocytes by flow cytometry $(n=12)$. Representative dot plots of CFSE-staining in lymphocytes other than B cells are shown. Statistical comparisons between rat lgG control and anti-PD-1 mAb were made using the Wilcoxon matched-pairs test. Differences were considered statistically significant at $P<0.05\left({ }^{*} P<0.05 ;{ }^{*} P<0.01\right)$

percentages of PD-1 expression were observed in $\mathrm{CD} 4^{+}$ $\mathrm{T}$ cells from blood of HTLV-1-infected patients with adult T-cell leukemia [36]. The frequencies of PD- $1^{+}$ cells were also higher in $\mathrm{CD} 4^{+} \mathrm{T}$ cells in blood and both $\mathrm{CD}^{+}$and $\mathrm{CD}^{+} \mathrm{T}$ cells in tumor-bearing $\mathrm{LN}$ from BCBL than mesenteric $\mathrm{LN}$ from $\mathrm{BLV}^{+}$and $\mathrm{BVL}^{-}$cattle. These data suggest that anergic $\mathrm{T}$ cells, which may be specific for lymphoma cells, were increased in total $\mathrm{CD} 4^{+}$or $\mathrm{CD} 8^{+} \mathrm{T}$ cells in BCBL. Moreover, the frequency of $\mathrm{PD}-1^{+} \mathrm{T}$ cells was higher in tumor-bearing $\mathrm{LN}$ than peripheral blood in cattle with lymphoma, and the same tendency was reported in patients with metastatic melanoma [37]. Immune tolerance by PD-1 expression in T cells follows $\mathrm{T}$-cell activation by continued epitope recognition in peripheral lymphoid tissue [38-42]. Thus, one can speculate that most tumor infiltrated PD- $1^{+} \mathrm{T}$ cells could be specific for lymphoma cells, and present tumor-associated antigen, but fail to be activated properly by the PD-1/PD-L1 pathway, resulting in the immune evasion of BLV-induced lymphoma cells.

To verify the relationship between PD-1 expression in $\mathrm{T}$ cells and antigen-specific immunosuppression, PD-1 expression analysis in antigen-specific $\mathrm{T}$ cells is required. Indeed, PD-1 upregulation was mainly observed in $\mathrm{CD}^{+}$ $\mathrm{T}$ cells specific for pathogens causing chronic infection in various infection and tumors, such as HIV and HTLV infection and mesenteric melanoma $[10,37,43]$. In this study, PD- 1 upregulation in total $\mathrm{CD} 4^{+}$and $\mathrm{CD} 8^{+} \mathrm{T}$ cells 


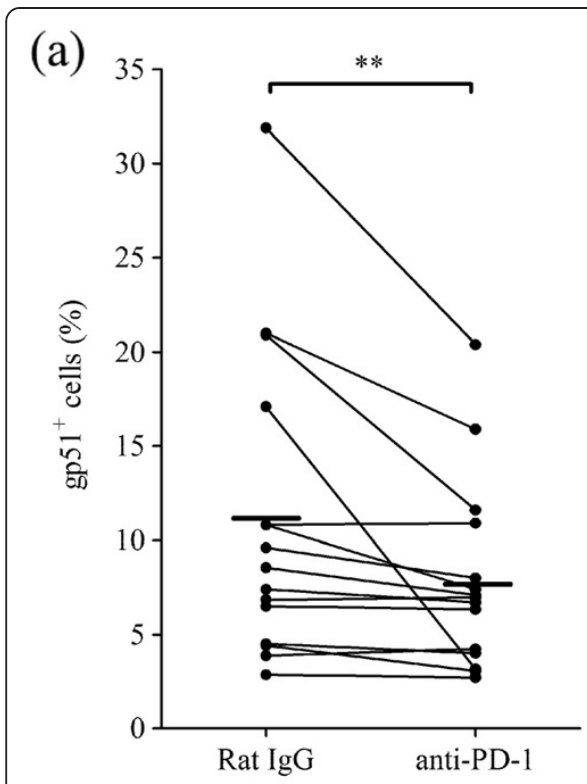

(b)

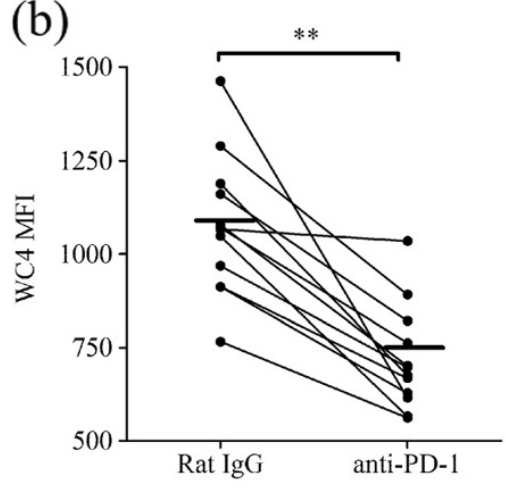

(c)
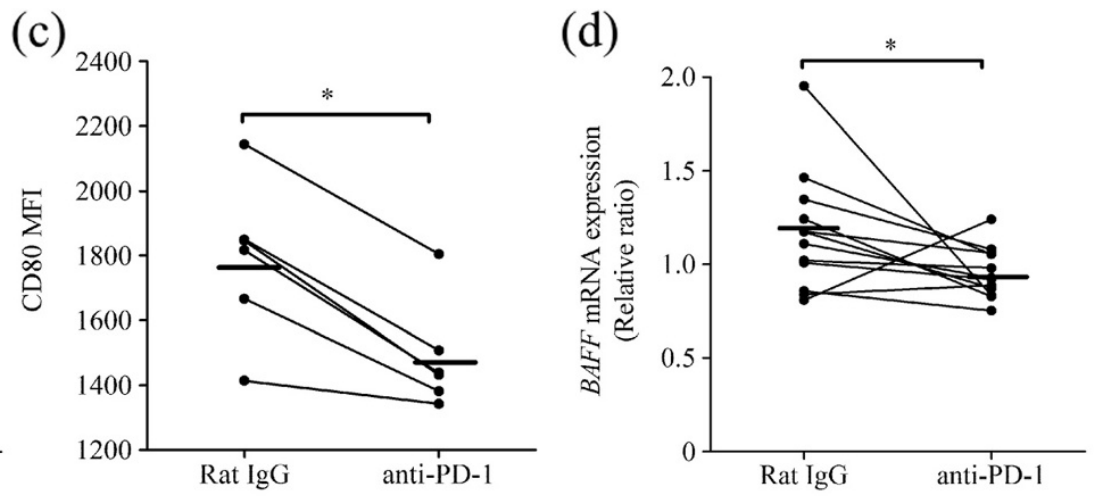

anti-PD-1

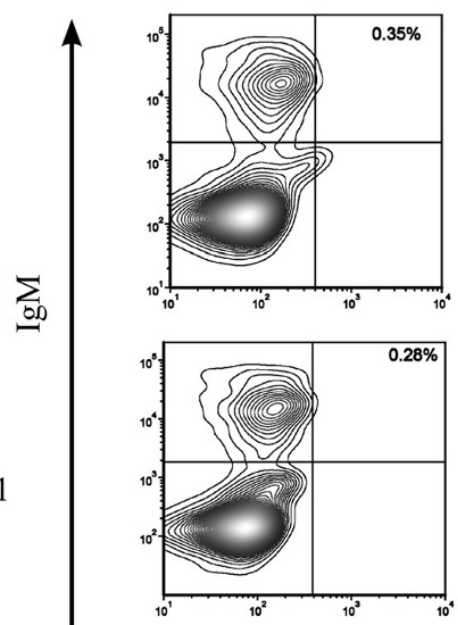

Anti-gp51
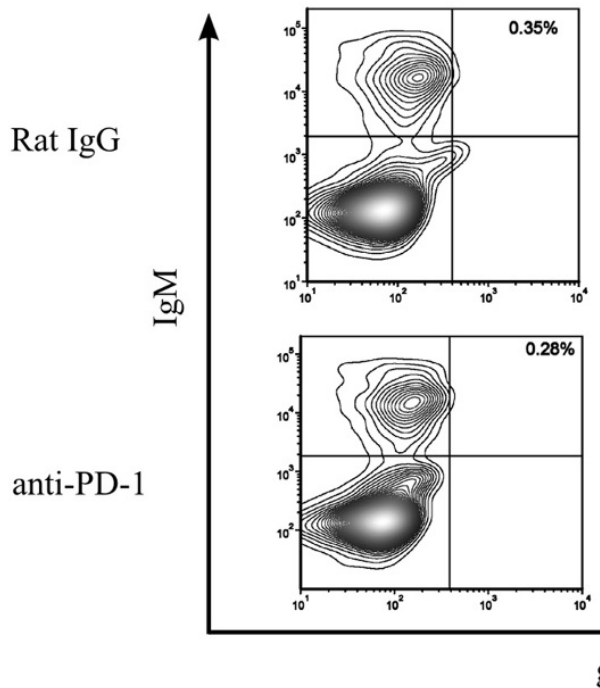

gp51
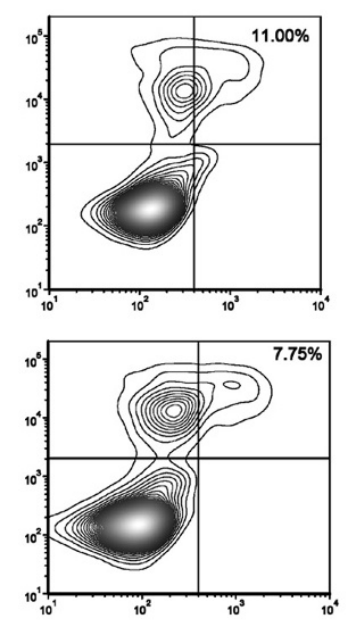

51 (e)

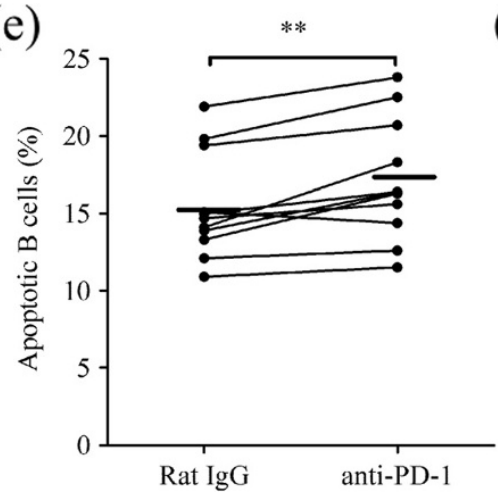


from $\mathrm{BLV}^{+}$cattle without lymphoma was not observed and PD-1 expression in BLV-specific T cells was not examined. Detection of BLV-specific T cells would enable more detailed analysis of PD-1, although the divergence of gene background of cattle complicates the establishment of MHC-tetramer which is an essential tool for detection. $\mathrm{BLV}^{+} \mathrm{B}$ cells are not eradicated by the immune system and proliferate in lymphoid tissue in vivo [44], so that BLV-specific $\mathrm{T}$ cells from $\mathrm{BLV}^{+}$cattle without lymphoma could recognize antigen continuously, express high PD-1 and lapse into an anergic state by PD-L1 expression in $\mathrm{BLV}^{+} \mathrm{B}$ cells.

In $\mathrm{BLV}^{+}$cattle with advanced stage of the disease, proliferation of $\mathrm{CD}^{+} \mathrm{T}$ cells in response to BLV proteins, such as gag and env, is impaired [6]. In this study, PD-1 blockade enhanced the IFN- $\gamma$ production in PBMC in response to the gp51 peptide mix. Moreover, the increasing rate of IFN- $\gamma$ production was correlated with percentages of $\mathrm{PD}-1^{+}$cells in $\mathrm{CD} 4^{+} \mathrm{T}$ cells, suggesting that PD-1 blockade invigorated the function of PD- $1^{+}$ CD4 ${ }^{+} \mathrm{T}$ cells, perhaps gp51-specific T cells. Meanwhile, IL-10 production was not altered in PBMC by treatment with anti-PD-1 mAb. Blockade of PD-1/PD-L1 pathway does not seem to upregulate all functions of PD-1 ${ }^{+} \mathrm{T}$ cells.

On the contrary, PD-1 blockade resulted in the inhibition of gp51 expression, reduced the expression of activation marker of B cells, WC4 and CD80 and increased B-cell apoptosis. Although the mechanism of BLV-gp51 expression both in vitro cultivation and in vivo is not dissolved, B-cell activation by immune-mediated stimulation is known as the important factor for activation of viral protein synthesis [31]. This study did not demonstrate that $\mathrm{T}$ cells reactivated by anti-PD-1 mAb have a direct effect on the B-cell activity. However, anti-PD-1 $\mathrm{mAb}$ did not directly affect $\mathrm{B}$ cells, because recognizable PD-1 expression was not observed in B cells and PD-1 treatment of isolated B cells did not alter gp51 expression. Changes in the cytokine environment, such as reduction of BAFF or activation of cytotoxic $\mathrm{T}$ cells induced by PD-1 blockade could create a disadvantageous environment for B cells, subsequently resulting in the reduction of gp51, WC4 and CD80 expression and increased B-cell apoptosis.

PD-1 is expected to be a potential target for reinvigorating the function of exhausted T cells. Many researchers have investigated antibody treatment that blocks the PD$1 / \mathrm{PD}-\mathrm{L} 1$ pathway $[11,43,45]$, and clinical trials in patients with cancer who were administered anti-PD-1 antibody are now ongoing [13,14]. Anti-bovine PD-1 $\mathrm{mAb}$ upregulated IFN- $\gamma$ production in PBMC from BLV ${ }^{-}$ cattle, indicating that the immune reactivation by PD-1 blockade is not a limited phenomenon in BLV infection. Although it is unknown whether PD-1 ${ }^{+} \mathrm{T}$ cells in $\mathrm{BLV}^{-}$ cattle are specific for some pathogens, there is the possibility that treatment with these anti-PD-1 mAb could be applied to new targets of therapy for many types of infection in cattle via upregulation of immune responses. Moreover, the mAb could promote research regarding bovine immunology and clarify the mechanisms of diseases that induce immunosuppression.

\section{Additional files}

\section{Additional file 1: An example of BLV-gp51 expression in freshly isolated and cultivated lymphocytes. Values in the quadrant indicate the percentage of $\mathrm{gp} 51^{+}$cells in lymphocytes.}

Additional file 2: IFN- $\gamma$ production in PBMC cultivated with peptide mixture and anti-PD-1 mAb treatment. Error bars represent the SEM of the means among the seven cattle. Statistical comparisons were made using one-way ANOVA with the Tukey's test.

\section{Abbreviations}

BCBL: Bovine leukemia virus-infected cattle with B-cell lymphoma; $B L V$ : Bovine leukemia virus; $\mathrm{BLV}^{+}$: Bovine leukemia virus-infected; BLV: Bovine leukemia virus-uninfected; CHO: Chinese hamster ovary; ELISA: Enzyme-linked immunosorbent assay; HRP: Horse radish peroxidase; IFN- $\gamma$ : Interferongamma; IL: Interleukin; LN: Lymph node; mAb: Monoclonal antibody; pAb: Polyclonal antibody; PBMC: Peripheral blood mononuclear cells; PBS: Phosphate-buffered saline; PBS-T: 0.05\% Tween 20 in phosphatebuffered saline; PD-1: Programmed death-1; PD-1-lg: Soluble PD-1-bovine IgG1 fusion protein; PD-L1: Programmed death-ligand 1; PMA: Phorbol 12-myristate acetate; PWM: Pokeweed mitogen; SDS-PAGE: Sodium dodecyl sulfate-polyacrylamide gel electrophoresis; sPD-1: Soluble form of programmed death-1.

\section{Competing interests}

The authors declare that they have no competing interests.

\section{Authors' Contributions}

RI performed all of the studies contained in this manuscript, analyzed data, and drafted the manuscript. SK participated in the experimental design, analyzed data, and helped to draft the manuscript. TO participated in some experiments and sample collection. KY, CN, and YS participated in the experiments involving expression and purification of soluble proteins, and reviewed the manuscript. SM helped with the experimental design and data interpretation. KO supervised the study and reviewed the manuscript. All authors read and approved the final manuscript.

\section{Acknowledgements}

This work was supported by Grants-in-Aid for Scientific Research from the Japan Society for the Promotion of Science (JSPS), and by a special grant for the Promotion of Basic Research Activities for Innovative Biosciences from the Bio-oriented Technology Research Advancement Institution (BRAIN). We are grateful to Dr Hideyuki Takahashi and Dr Yoshiyuki Goto, National Agriculture and Food Research Organization, BRAIN, for valuable advice and discussion.

\section{Author details}

${ }^{1}$ Department of Disease Control, Graduate School of Veterinary Medicine, Hokkaido University, Sapporo 060-0818, Japan. ${ }^{2}$ Research Center for Zoonosis Control, Hokkaido University, Sapporo 001-0020, Japan.

Received: 9 January 2013 Accepted: 25 June 2013

Published: 22 July 2013

\section{References}

1. Dunn GP, Old LJ, Schreiber RD: The immunobiology of cancer immunosurveillance and immunoediting. Immunity 2004, 21:137-148.

2. Keir ME, Butte MJ, Freeman GJ, Sharpe AH: PD-1 and its ligands in tolerance and immunity. Annu Rev Immunol 2008, 26:677-704. 
3. Kabeya $H$, Ohashi $\mathrm{K}$, Onuma M: Host immune responses in the course of bovine leukemia virus infection. J Vet Med Sci 2001, 63:703-708.

4. Asquith B, Bangham C, Bouzar A, Gillet N, Defoiche J, Florins A: Gene activation therapy: from the BLV model to HAM/TSP patients. Front Biosci 2009, 1:205-215

5. Gutierrez S, Ceriani C, Juliarena M, Ferrer JF: Host soluble factors that regulate the synthesis of the major core protein of the bovine leukemia virus (BLV) in a naturally infected neoplastic B-cell line. Vet Immunol Immunopathol 2009, 131:246-258.

6. Orlik O, Splitter GA: Progression to persistent lymphocytosis and tumor development in bovine leukemia virus (BLV)-infected cattle correlates with impaired proliferation of $\mathrm{CD}^{+} \mathrm{T}$ cells in response to gag- and env-encoded BLV proteins. J Virol 1996, 70:7584-7593.

7. Rosignoli G, Lim CH, Bower M, Gotch F, Imami N: Programmed death (PD)-1 molecule and its ligand PD-L1 distribution among memory CD4 and CD8 T cell subsets in human immunodeficiency virus-1-infected individuals. Clin Exp Immunol 2009, 157:90-97.

8. Elrefaei M, Baker CA, Jones NG, Bangsberg DR, Cao H: Presence of suppressor HIV-specific CD8 ${ }^{+}$T cells is associated with increased PDexpression on effector CD8 ${ }^{+}$T cells. J Immunol 2008, 180:7757-7763.

9. Matsuzaki J, Gnjatic S, Mhawech-Fauceglia P, Beck A, Miller A, Tsuji T, Eppolito C, Qian F, Lele S, Shrikant P, Old LJ, Odunsi K: Tumor-infiltrating NY-ESO-1-specific CD8 ${ }^{+} T$ cells are negatively regulated by LAG-3 and PD-1 in human ovarian cancer. Proc Natl Acad Sci U S A 2010, 107:7875-7880

10. Kozako T, Yoshimitsu M, Fujiwara H, Masamoto I, Horai S, White Y, Akimoto M, Suzuki S, Matsushita K, Uozumi K, Tei C, Arima N: PD-1/PD-L1 expression in human T-cell leukemia virus type 1 carriers and adult T-cell leukemia/ lymphoma patients. Leukemia 2009, 23:375-382

11. Velu V, Titanji K, Zhu B, Husain S, Pladevega A, Lai L, Vanderford TH, Chennareddi L, Silvestri G, Freeman GJ, Ahmed R, Amara RR: Enhancing SIV-specific immunity in vivo by PD-1 blockade. Nature 2009, 458:206-210.

12. Finnefrock AC, Tang A, Li F, Freed C, Feng M, Cox KS, Sykes KJ, Guare JP, Miller MD, Olsen DB, Hazuda J, Shiver JW, Casimiro DR, Freed DC, Hazuda DJ, Fu T: PD-1 blockade in rhesus macaques: impact on chronic infection and prophylactic vaccination. J Immunol 2010, 182:980-987.

13. Brahmer J, Drake CG, Wollner I, Powderly JD, Picus J, Sharfman WH, Stankevich E, Pons A, Salay TM, McMiller TL, Gilson MM, Wang C, Selby M, Taube JM, Anders R, Chen L, Korman AJ, Pardoll DM, Lowy I, Topalian SL: Phase I study of single-agent anti-programmed death-1 (MDX-1106) in refractory solid tumors: safety, clinical activity, pharmacodynamics, and immunologic correlates. J Clin Oncol 2010, 28:3167-3175.

14. Berger R, Rotem-Yehudar R, Slama G, Landes S, Kneller A, Leiba M, KorenMichowitz M, Shimoni A, Nagler A: Phase I safety and pharmacokinetic study of CT-011, a humanized antibody interacting with PD-1, in patients with advanced hematologic malignancies. Clin Cancer Res 2008, 14:3044-3051.

15. Jeon D, Oh K, Oh BC, Nam DH, Kim CH, Park H, Cho J, Lee JR, Lee D, Lee G: Porcine PD-L1: cloning, characterization, and implications during xenotransplantation. Xenotransplantation 2007, 14:236-242.

16. Peng J, Tian Z, Liu H, An T, Zhou Y, Wang Y, Li D, Chen J, Yang Y, Tong G: Cloning and identification of porcine programmed death 1. Vet Immunol Immunopathol 2010, 136:157-162.

17. Matsuyama-Kato A, Murata S, Isezaki M, Kano R, Takasaki S, Ichii O, Konnai S, Ohashi K: Molecular characterization of immunoinhibitory factors PD-1 /PD-L1 in chickens infected with Marek's disease virus. Virol J 2012, 9:94

18. Folkl A, Wen X, Kuczynski E, Clark ME, Bienzle D: Feline programmed death and its ligand: characterization and changes with feline immunodeficiency virus infection. Vet Immunol Immunopathol 2010, 134:107-114.

19. Ikebuchi $R$, Konnai S, Shirai T, Sunden Y, Murata S, Onuma M, Ohashi K Increase of cells expressing PD-L1 in bovine leukemia virus infection and enhancement of anti-viral immune responses in vitro via PD-L1 blockade. Vet Res 2011, 42:103.

20. Ikebuchi R, Konnai S, Sunden Y, Onuma M, Ohashi K: Molecular cloning and expression analysis of bovine programmed death-1. Microbiol Immunol 2010, 54:291-298.

21. Said EA, Dupuy FP, Trautmann L, Zhang Y, Shi Y, El-Far M, Hill BJ, Noto A, Ancuta P, Peretz Y, Fonseca SG, Grevenynghe JV, Boulassel MR, Bruneau J, Shoukry NH, Routy J, Douek DC, Haddad EK, Sekaly R: Programmed death- 1-induced interleukin-10 production by monocytes impairs $\mathrm{CD} 4^{+} \mathrm{T}$ cell activation during HIV infection. Nat Med 2010, 16:452-459.

22. Niwa H, Yamamura K, Miyazaki J: Efficient selection for high-expression transfectants with a novel eukaryotic vector. Gene 1991, 108:193-199.

23. Arase $H$, Mocarski ES, Campbell AE, Hill AB, Lanier LL: Direct recognition of cytomegalovirus by activating and inhibitory NK cell receptors. Nat Immunol 2002, 296:1323-1326.

24. Naessens J, Howard CJ, Hopkins J: Nomenclature and characterization of leukocyte differentiation antigens in ruminants. Immunol Today 1997, 18:365-368.

25. Janossy G, Gomez De La Concha E, Waxadal MJ, Platts-Mills T: The effects of purified mitogenic proteins (Pa-1 and $\mathrm{Pa}-2)$ from pokeweed on human T and B lymphocytes in vitro. Clin Exp Immunol 1976, 26:108-117.

26. Agata $Y$, Kawasaki A, Nishimura $H$, Ishida $Y$, Tsubata $T$, Yagita $H$, Honjo $T$ : Expression of the PD-1 antigen on the surface of stimulated mouse $T$ and B lymphocytes. Int Immunol 1996, 8:765-772.

27. Grzywnowicz M, Zaleska J, Martens D, Tomczak W, Wlasiuk P, Kosior K, Piechnik A, Bojarska-Junak A, Dmoszynska A, Giannopoulos K: Programmed death-1 and its ligand are novel immunotolerant molecules expressed on leukemic B cells in chronic lymphocytic leukemia. PLoS One 2012, 7:e35178.

28. Gupta P, Ferrer JF: Expression of bovine leukemia virus genome is blocked by a nonimmunoglobulin protein in plasma from infected cattle. Science 1982, 215:405-407.

29. Gupta P, Kashmiri SV, Ferrer JF: Transcriptional control of the bovine leukemia virus genome: role and characterization of a nonimmunoglobulin plasma protein from bovine leukemia virus-infected cattle. J Virol 1984, 50:267-270.

30. Tajima S, Aida Y: Induction of expression of bovine leukemia virus (BLV) in blood taken from BLV-infected cows without removal of plasma. Microbes Infect 2005, 7:1211-1216.

31. Gillet N, Florins A, Boxus M, Burteau C, Nigro A, Vandermeers F, Balon H, Bouzar A-B, Defoiche J, Burny A, Reichert M, Kettmann R, Willems L: Mechanisms of leukemogenesis induced by bovine leukemia virus: prospects for novel anti-retroviral therapies in human. Retrovirology 2007, 4:18.

32. Lied GA, Berstad A: Functional and clinical aspects of the B-cell-activating factor (BAFF): a narrative review. Scand J Immunol 2011, 73:1-7.

33. Nielsen C, Ohm-Laursen L, Barington T, Husby S, Lillevang ST: Alternative splice variants of the human PD-1 gene. Cell Immunol 2005, 235:109-116.

34. Wan B, Nie H, Liu A, Feng G, He D, Xu R, Zhang Q, Dong C, Zhang JZ: Aberrant regulation of synovial $T$ cell activation by soluble costimulatory molecules in rheumatoid arthritis. J Immunol 2006, 177:8844-8850.

35. Flies DB, Wang $S, X u H$, Chen L: A monoclonal antibody specific for the programmed death-1 homolog prevents graft-versus-host disease in mouse models. J Immunol 2011, 187:1537-1541.

36. Shimauchi T, Kabashima K, Nakashima D, Sugita K, Yamada Y, Hino R, Tokura $Y$ : Augmented expression of programmed death-1 in both neoplastic and non-neoplastic CD4 ${ }^{+}$T-cells in adult T-cell leukemia/lymphoma. Int $J$ Cancer 2007, 121:2585-2590.

37. Ahmadzadeh M, Johnson LA, Heemskerk B, Wunderlich JR, Dudley ME, White DE, Rosenberg SA: Tumor antigen-specific CD8 T cells infiltrating the tumor express high levels of PD-1 and are functionally impaired. Blood 2009, 114:1537-1544

38. Tsushima F, Yao S, Shin T, Flies A, Flies S, Xu H, Tamada K, Pardoll DM, Chen $\mathrm{L}$ : Interaction between $\mathrm{B} 7-\mathrm{H} 1$ and PD-1 determines initiation and reversal of T-cell anergy. Blood 2007, 110:180-185.

39. Fife BT, Bluestone JA: Control of peripheral T-cell tolerance and autoimmunity via the CTLA-4 and PD-1 pathways. Immunol Rev 2008, 224:166-182.

40. Blattman JN, Wherry EJ, Ha SJ, Most RG, Ahmed R: Impact of epitope escape on PD-1 expression and CD8 T-cell exhaustion during chronic infection. J Virol 2009, 83:4386-4394.

41. Richter $K$, Agnellini $P$, Oxenius $A$ : On the role of the inhibitory receptor LAG-3 in acute and chronic LCMV infection. Int Immunol 2009, 22:13-23.

42. Streeck H, Brumme ZL, Anastario M, Cohen KW, Jolin JS, Meier A, Brumme CJ, Rosenberg ES, Alter G, Allen TM, Walker BD, Altfeld M: Antigen load and viral sequence diversification determine the functional profile of HIV-1 -specific CD8 ${ }^{+}$T cells. PLoS Med 2008, 5:e100.

43. Trautmann L, Janbazian L, Chomont N, Said EA, Gimmig S, Bessette B, Boulassel M, Delwart E, Sepulveda H, Balderas RS, Routy J, Haddad EK, Sekaly 
R: Upregulation of PD-1 expression on HIV-specific CD $8^{+} \mathrm{T}$ cells leads to reversible immune dysfunction. Nat Med 2006, 12:1198-1202.

44. Debacq C, Gillet N, Asquith B, Sanchez-Alcaraz MT, Florins A, Boxus M, Schwartz-Cornil I, Bonneau M, Jean G, Kerkhofs P, Hay J, Thewis A, Kettmann $\mathrm{R}$, Willems L: Peripheral blood B-cell death compensates for excessive proliferation in lymphoid tissues and maintains homeostasis in bovine leukemia virus-infected sheep. J Virol 2006, 80:9710-9719.

45. Hirano F, Kaneko K, Tamura H, Dong H, Wang S, Ichikawa M, Rietz C, Flies DB, Lau JS, Zhu G, Tamada K, Chen L: Blockade of B7-H1 and PD-1 by monoclonal antibodies potentiates cancer therapeutic immunity. Cancer Res 2005, 65:1089-1096.

doi:10.1186/1297-9716-44-59

Cite this article as: lkebuchi et al: Blockade of bovine PD-1 increases T cell function and inhibits bovine leukemia virus expression in B cells in vitro. Veterinary Research 2013 44:59.

\section{Submit your next manuscript to BioMed Central and take full advantage of:}

- Convenient online submission

- Thorough peer review

- No space constraints or color figure charges

- Immediate publication on acceptance

- Inclusion in PubMed, CAS, Scopus and Google Scholar

- Research which is freely available for redistribution 